DOI: https://doi.org/10.32689/2523-4536/63-10

УДК 339.138:338.534

Скригун Н. П.

кандидат економічних наук, доцент,

Національний університет харчових технологій ORCID: https://orcid.org/0000-0003-1014-4393

Бойко I. A.

кандидат економічних наук,

Національний університет харчових технологій

ORCID: https://orcid.org/0000-0002-4549-9584

Гайдуков Д. С.

студент,

Національний університет харчових технологій

Skryhun Nataliia

Candidate of Economic Sciences, Associate Professor of Marketing Department,

National University of Food Technology

Boiko Iryna

Candidate of Economic Sciences, Associate Professor of Marketing Department,

National University of Food Technology

Haidukov Dmytro

Student,

National University of Food Technology

\title{
ПСИХОЛОГІЧНІ ЕФЕКТИ СПРИЙНЯТТЯ ЦІНИ ПІД ЧАС ФОРМУВАННЯ ЦІННОСТІ БРЕНДУ
}

\section{PSYCHOLOGICAL EFFECTS OF PRICE PERCEPTION IN FORMING OF BRAND VALUE}

\footnotetext{
У статті розглянуто основні психологічні ефекти сприйняття иіни спожсивачами, розкрито маркетингову сутність кожного з них. Визначено, що сприйняттям иіни можна управляти маркетинговими інструментами. Установлено, щчо для того, аби повідомити покупџю ціну товару та знизити його чутливість до рівня ціни, використовують різноманітні психологічні ефекти сприйняття иіни. Проаналізовано доиільність використання заокруглених цін та їхній вплив на свідомість потенційних споживачів. Розкрито сутність такого поняття, як «цінність бренду», наведено ї̈ характеристики та основні відмінності від иіни товару, визначено основні умови формування цінності бренду, а також ї̈ вплив на споживачів та їхні купівельні пріоритети. Наведено основні та додаткові переваги надання брендам изінності, яка б впливала на купівельні рімення споживачів; напрями створення основної иінності товару.
}

Ключові слова: цุіна, сприйняття ціни, ијінність бренду, споживач, психологічний ефект сприйняття изіни.

The problem of the effective pricing is actual nowadays, in fact the price is the factor where the potential customers pay special attention during the choice of commodity or service. The search of balance between mark- on the commodity and level of population's solvency is success of the enterprise. The special attention is paid by the researches of price perception by the consumer and his psychology, determinations of psychological methods, on the basis of the pricing process, and analysis of brand value, passes as a separate aspect that directly influences on the cost of brand. The main purpose is describing the essence of different psychological effects, that influence on consumers' price perception and methods that marketing specialists use during the forming of brand value is given in this article. At forming of price, it is needed to take into account psychological effects of price perception that is followed by majority of potential customers in the process of choice of commodity or service. Basic psychological effects that influence on consumers' perception of commodity cost during the process of purchase are determined in the article. To such effects belong: effect of comparison, id est that, how the potential consumer reacts on the commodity cost, comparing its with analogue; effect of contrast that helps to increase volumes sale; effect of extreme variants, that is used mostly in the service; effect of relativity, that proves that people can perceive the same discount in different way. The effect of honesty, odd prices and other price effects that influence on consumer's choice during the process of commodities acquisition is investigated. Basic methods, which are followed by producers during the forming of price on new commodity or service, are given. Among such methods, it is possible to distinguish the cost of prestige and free supply price. The essence of concept of brand value, its descriptions over and basic differences from the commodity cost is exposed; the basic terms of forming of brand value and its influence on consumers and their purchasing properties are given. Basic and additional advantages of brand value that would influence on the purchasing decisions of consumers are described. Directions of creation of basic advantages of brands value are analysed. The influence of experience of the commodity use 
on its general value in the consumer's eyes is investigated. The influence positioning of brands on their perception, external aspects, such as commodity packing and its design, and their influence on the brand value are analysed. General reputation of producer and consumers'emotions automatically create additional demand on the commodity, increasing its value is marked.

Keywords: price, price perception, brand value, consumer, psychological effect of price perception.

Постановка проблеми. Основною метою функціонування будь-якого підприємства є отримання прибутку, який, своєю чергою, залежить від багатьох чинників, ключовим з яких є ціна товару. Проблема маркетингового ціноутворення $\epsilon$ досить актуальною, адже саме ціна є тим чинником, на який потенційні покупці звертають особливу увагу під час вибору товару або послуги. Формування ціни є доволі складним та водночас важливим завданням для підприємства, адже необхідно знайти баланс між націнкою на товар та рівнем платоспроможності населення. Основним завданням маркетологів у цьому разі $\epsilon$ аналіз ринку та використання одного з наявних методів ціноутворення задля успішного продажу товару в майбутньому. Також під час процесу формування ціни слід ураховувати певні психологічні ефекти сприйняття ціни, якими керується переважна більшість потенційних покупців у процесі вибору товару чи послуги.

Аналіз останніх досліджень і публікацій. Проблемами методології ціноутворення та вивченням психологічних ефектів, які впливають на сприйняття ціни, займається низка закордонних та вітчизняних учених, серед яких: Х.М. Беспалюк, Н.I. Горбаль, О.В. Денисюк, З.Б. Живко, В.Л. Корінєв, В.М. Мельникович, М.М. Окландер, С.Б. Розумей, К.В. Чичуліна, О.П. Чукурна та ін., які досліджували сутність понять «цінова політика», «цінова стратегія», «цінова тактика», «цінова психологія», а також розкривали основну сутність ціноутворення, обгрунтовували вибір певних цінових стратегій для тієї чи іншої ситуації.

Однак, незважаючи на значну кількість досліджень у цій сфері, деякі окремі аспекти психологічних ефектів, якими керуються потенційні споживачі під час вибору товару, вимагають подальшого вивчення. Зокрема, особливої уваги потребують дослідження сприйняття ціни споживачем та його психології, визначення психологічних методів, на основі яких проходить процес ціноутворення, а також аналіз цінності бренду як окремого аспекту, що безпосередньо впливає на ціну бренду.

Мета статті полягає у розкритті сутності окремих психологічних ефектів, які впливають на сприйняття ціни споживачами, а також методів, якими керуються маркетологи під час формування цінності бренду. Для досягнення поставленої мети у статті передбачено вирішити такі завдання: розглянути сутність психологічних ефектів сприйняття ціни; визначити основні методи ціноутворення; дослідити ключові відмінності між поняттями ціни та цінності товару або бренду.
Виклад основного матеріалу. Ціноутворення товарів або послуг на основі психології $€$ своєрідною маркетинговою стратегію, що заснована на теорії, згідно з якою певні ціни надають більший психологічний вплив на споживачів, аніж інші. Психологія сприйняття покупцем цін суттєво впливає на ефективність діяльності підприємства, тому необхідно прогнозувати можливу реакцію покупців на рівень та складники ціни, під час формування якої враховувати різноманітні психологічні чинники, що зумовлюють таку реакцію [1]. На думку К.В. Чичуліної та Я.О. Кладченко, «цінова психологія продавців $\epsilon$ не що інше, як використання психологічних факторів і психології поведінки осіб, що пропонують товар за певними цінами, у ході реалізації однієї 3 названих цінових стратегій або їх поєднання» [6]. Психологія ціни використовує так званий емоційний відгук клієнта 3 метою заохочення угоди. Так, за деякими важливими асортиментними позиціями компанія може суттєво збільшити продаж навіть без істотного зниження цін. В окремих випадках, навпаки, вища ціна здатна збільшити продаж. На споживчому сприйнятті цін на товари чи послуги базується стратегія психологічного ціноутворення. Замість того, аби звертатися до потенційних клієнтів з раціонального погляду, дана стратегія фокусується саме на їхньому емоційному складнику. Для одного клієнта ціноутворення може бути націлене на позитивне відчуття від удалої покупки з помітною вигодою, для іншого - на почуття престижу від усвідомлення того, що він може придбати якісний та елітний продукт. Тобто психологічні ефекти сприйняття ціни можуть бути різними, i базуються вони виключно на потребах цільової аудиторії [1].

Існує значна кількість психологічних аспектів, що їх необхідно враховувати під час ціноутворення. І.Г. Майоров та Н.Г. Майорова виокремлюють такі основні чотири групи психологічні методів, які засновані на: сприйнятті ціни та іiі змін як певних математичних величин; сприйнятті порівняння цін; особливостях психологічного сприйняття людиною корисності і вигід від покупки; особливостях психологічного портрету споживачів [3].

Сприйняття ціни залежить від типу поведінки споживачів. Водночас сприйняттям ціни можна управляти маркетинговими інструментами. Для того щоб повідомити покупцю ціну товару та знизити його чутливість до рівня ціни, використовують різноманітні психологічні ефекти сприйняття ціни [4].

Одним iз найпоширеніших психологічних ефектів сприйняття ціни $є$ ефект референсів, або 
порівняння. Він базується на тому, що потенційні клієнти самостійно не можуть визначити справедливу вартість товару, їм потрібно фокусуватися на окремих перевагах однієї пропозиції над іншою. Споживачам подобається порівнювати ціну одного товару з іншим, тому важливим завданням для виробника $є$ перехоплення ініціативи, аби самостійно встановити основні критерії для порівняння на користь свого товару. Причому виробникам навіть не обов'язково порівнювати свій товар чи послугу з конкурентами, достатньо дати клієнтам можливість порівняти ціну з будьяким іншим повсякденним товаром та показати невелику різницю у ціні та значну - у користі та цінності свого товару.

Іншим доволі схожим ефектом сприйняття ціни є ефект контрасту, який вигідний виключно продавцям. Його основна сутність полягає у тому, що під час покупки дорогого товару (автомобіль, квартира тощо) клієнтам пропонуються додаткові товари, аксесуари, послуги, ціна яких є значно нижчою від основного товару, а тому клієнти на тлі ефекту контрасту зазвичай не відмовляються від даних пропозицій та купують їх.

Набуває поширення $\mathrm{i}$ такий психологічний ефект сприйняття ціни, як ефект екстремальних варіантів. Психологічна сутність цього ефекту полягає у тому, що люди схильні уникати крайнощів, тому в магазинах біля окремих товарів на полиці виставляють товари вищої цінової категоpiï, на тлі яких ціна основного товару видається споживачеві оптимальною. Асортиментний ряд товарів часто доповнюють так, аби перед дорогим товаром знаходився ще значно дорожчий, на тлі якого ціни дорогих товарів здаються прийнятнішими (метод «добудови шпиля»).

Дослідження показали, що покупцям не подобається виглядати бідними, (особливо якщо про це треба заявити відкрито, наприклад зробивши замовлення в кафе, ресторані), тому найдешевші позиції в меню люди замовляють так само рідко, як і штучно створені найдорожчі. Відповідно, на ті позиції, які розміщуються посередині, може ставитися найвища націнка, і вони, як правило, будуть найприбутковішим для підприємства.

Такий психологічний ефект сприйняття ціни, як ефект відносності, полягає у тому, що знижки на товари $є$ доволі відносними, якщо порівнювати 3 дорожчими товарами. Так, наприклад, за знижкою в 100 грн за товаром, вартість якого становить 300 грн, люди готові їхати в інший кінець міста. Тут спрацьовує також і ефект вигоди від купівлі, який також $є$ штучним. Однак якщо та ж знижка буде, наприклад, на товар, який коштує 20 тис грн, то для потенційного покупця вона здаватиметься несуттєвою. Тому у разі коли розмір знижки порівняно 3 повною вартістю товару $\epsilon$ незначним, то виробнику або продавцю варто перекласти знижку на інший товар. Наприклад, не $0,5 \%$ знижка на автомобіль, а $40 \%$ знижка на відеореєстратор чи на страхування авто.
Ефект чесності як психологічний ефект сприйняття ціни в умовах сучасності спрацьовує також досить добре, адже покупцям не подобається, коли їх обманюють. Тобто у разі якщо через інфляцію чи інші чинники виробник вимушений підвищити ціну на свої товари чи послуги, він повинен пояснити зміну в ціні споживачам, інакше у них складеться враження, що їх вводять в оману. Задля утримання лояльних споживачів окремі відомі виробники проводять навіть рекламні кампанії, у яких пояснюють причини зростання цін та свої товари чи послуги. Такий спосіб є доволі дієвим, адже лояльні споживачі $є$ найціннішими клієнтами для компанії.

Найбільш поширеним психологічним ефектом сприйняття ціни також $\epsilon$ ефект фреймінгу, або ефект незаокруглених цін. Цей поведінковий прояв психології сприйняття можна назвати закріплюючим ефектом лівої цифри. Ця гіпотеза передбачає, що люди сприймають різницю між 89,90 і 100,0 ближче до 20,1, ніж до 10,1 , тому що їхні судження прив'язані до лівої цифри. Споживачі переважно ігнорують менш значні цифри і не займаються коректним округленням. Незважаючи на те що копійки видно, вони можуть підсвідомо їх ігнорувати та округлити ціну. Можливо, цей ефект може бути посилений, коли копійки друкуються меншим шрифтом [2]. Однак, незважаючи на те що ціна 199,9 виглядає краще, ніж 200,00, останнім часом довіра споживачів вища до цін із дробовими нестандартними поділами, наприклад 186,7. Така ціна виглядає більш реалістичною, i потенційним споживачам здається, що компанія поставила мінімально доступну націнку на товар. Щодо закреслених колишніх цін, то покупці, звісно, розуміють, що цим прийомом їх можуть уводити в оману, але відчуття вигідності угоди під час покупки все одно залишається.

Також виробники деяких окремих груп товарів у своєму ціноутворенні можуть використовувати такий метод, як ціна престижу, який є повною протилежністю методу незаокруглених цін. Основна сутність стратегії передбачає використання лише цілих чисел у ціні (замість 999,00 на ціннику вказується 1000). Такий ефект престижу керується тим, що люди в окремих ситуаціях краще сприймають числа 3 меншою кількістю складів, навіть якщо число більше. Для зменшення довжини цінника часто видаляють коми, адже круглі числа найпростіше обробляються свідомістю споживача. Купівля таких товарів зумовлена саме почуттями споживачів, а не розрахунками та накопиченими знаннями про ціни на товари-аналоги. Із психологічного погляду точні цифри викликають асоціації 3 невеликими значеннями i, таким чином, впливають на сприйняття покупців.

Нині стає все менш актуальним такий психологічний ефект сприйняття ціни, як «біль» покупця під час оплати товару завдяки можливості оплати банківськими картками, безконтактної оплати 3 телефонів чи браслетів. 
Невід'ємним психологічним ефектом $є$ ефект «сигналів якості». Щоразу під час покупок у магазині споживачі намагаються вибрати кращий товар 3-поміж наявного асортименту. Але, на жаль, досвіду багатьох покупців недостатньо для того, аби оцінити якість товару, просто подивившись на нього, тому споживачі починають покладатися на легкі та вимірні сигнали, які, на їхню думку, говорять про високу якість.

Окрім психологічних ефектів, на остаточний вибір споживача впливає також і цінність пропозиції. Іноді саме вона стає вирішальним чинником, яким керується споживач під час вибору товару чи послуги. Якщо покупець може легко розрахувати цінність певної пропозиції та порівняти іiї з пропозиціями конкурентів, то якість продукції визначає іiї ціну. Якщо ж цінність продукту незрозуміла і іiі складно порахувати, то цей принцип працює навпаки, і саме ціна товару починає визначати його якість (спрацьовує ефект оцінювання якості товару через ціну). Саме тому у підсвідомості сформувався сталий ефект, який говорить, що чим дорожчим $\epsilon$ товар, то вищою $\epsilon$ його якість [5].

Психологія сприйняття ціни покупцями також цікава тим, що кожну покупку людина підсвідомо відносить до певного «рахунку» у своїй голові. За одними рахунками клієнт допускає більші витрати, а за іншими - менші витрати. Віднесення саме вашого товару або послуги на той чи інший рахунок абсолютно не пов'язане 3 певними розрахунками чи характеристиками продукту, воно $\epsilon$ абсолютно суб'єктивним. Тому виробник чи продавець не може вплинути на даний ефект сприйняття ціни покупцями.

Дієвим методом, який впливає на психологічне сприйняття ціни, $є$ сила безкоштовної пропозиції. Людям подобається отримувати щось безкоштовно. Широковідомим є факт, що коли покупець отримує невеликий подарунок, йому хочеться віддячити тому, хто його подарував. На цьому принципі й побудована вся індустрія акцій, знижок, спеціальних пропозицій, семплінгів та дегустацій. Коли покупець отримує подарунок, то починає вважати, що має щось купити натомість, особливо якщо подарунок виявився корисним. Можливість отримати товар безкоштовно приваблює споживача навіть більше, ніж гарантована знижка.

Невід'ємним складником, який впливає на процес сприйняття ціни покупцями, є цінність бренду. Іншими словами, що важливішим та ціннішим для споживача $є$ певний бренд, то вищу ціну він готовий заплатити, аби його придбати. Цінностями бренду є це не лише функціональність та якість товару, а й передусім його певні супутні позитивні характеристики, що відрізняють бренд від інших товарів-аналогів. Зазвичай люди хочуть не просто якісні та функціональні товари, вони вибирають бренди, які принесуть їм певну додаткову користь. Саме тому цінність бренду досить часто стає вирішальним чинником під час вибору товару чи послуги.

Цінностями бренду можуть виступати почуття та емоції, які бренд несе разом зі своїми споживчими характеристиками. Так, наприклад, людина, яка придбала собі товар певного бренду, може відчувати себе приналежною до якоїсь конкретної соціальної групи, відчувати престиж від покупки, бути впевненою у високій якості та надійності товару тощо. Усі ці нематеріальні якості дають споживачеві особливе задоволення від використання бренду.

Із погляду теорії брендингу товар має три ключові виміри, які безпосередньо впливають на купівельні рішення споживачів, забезпечуючи його цінність. До таких вимірів належать: основні переваги; додаткові переваги; розширені переваги. Своєю чергою, основні переваги включають у себе: досвід використання; сприйняття споживачів; зовнішній аспект (упаковка); загальна репутація виробника; особисті емоційні підстави споживачів. Досвід використання товару відіграє важливу роль та збільшує лояльність споживачів до бренду. Якщо за певний проміжок часу продукція зарекомендувала себе досить добре, то вироби торгової марки здобувають таку додану цінність, як упізнаваність та надійність. Те, як споживачі сприймають товар, залежить від того, як той чи інший бренд його позиціонує, тобто уявляє себе у рекламі. Так, наприклад, якщо бренд використовує здебільшого престижну рекламу, то споживачі сприймають його як щось особливо цінне та асоціюють себе з ним.

Під час вибору товару споживачі першочергово звертають увагу саме на зовнішні аспекти товару, тобто його упаковку, iї дизайн, якість матеріалів тощо. Загальна цінність бренду залежить від імені та репутації виробника. У практиці маркетингу досить часто загальновідоме ім'я компанії присвоюється ії новому товару, а разом із ним викликає і низку позитивних асоціацій. Цей підхід викликає у потенційних споживачів більшу довіру до пропонованого товару i, як наслідок, бажання його придбати. Певні емоційні підстави теж входять до основних переваг під час формування цінності бренду. Коли споживачі користуються продукцією дороговартісних та відомих брендів, вони, таким чином, заявляють свій особливий стиль життя, інтереси, цінності, рівень добробуту, а також, звісно, свій статус. Серед напрямів створення додаткової цінності бренду варто виокремити такі: підвищення рівня візуалізації бренду; упровадження інновацій, які орієнтовані на підвищення цінності бренду для споживачів; диференціація бренду, що дає можливість потенційним покупцям отримати додаткові відчутні та невідчутні переваги від користування брендом; репозиціювання на основі наявних технологій та засобів реклами і комунікації задля адаптації цінності бренду до ринкових умов; переформатування та зміна дистрибуції товарів задля того, аби зробити бренд доступнішим для покупців. 
Висновки. Отже, ціна товару чи послуги $\epsilon$ одним із ключових елементів, якими керуються споживачі під час свого вибору. Сприйняття ціни потенційними споживачами може сприйматися по-різному залежно від виду товару, психологічних ефектів та методів ціноутворення, які використали виробники під час формування ціни та товар. Також не менш важливим чинником під час вибору товару є його цінність в очах споживачів. Цінність товару відіграє вирішальну роль, адже вона $є$ основною відмінністю між товаром та його аналогами. Що вищою $є$ цінність певного бренду для споживача, то більшою є ймовірність його покупки.

\section{Список використаних джерел:}

1. Беспалюк Х.М., Горбаль Н.І., Денисюк О.В. Психологічні чинники при формуванні тактики ціноутворення. Маркетинг і менеджмент інноваиіи. 2018. № 1. С. 141-151.

2. Комиссаров К. Психология цены. URL: https://cutt.ly/HYUtSo3 (дата звернення: 10.12.2021).

3. Майоров И.Г., Майорова Н.Г. Психологические методы ценообразования. Инновации. Наука. Образование. 2020. № 15. C. 28-39. URL: https://cutt.ly/MYItIP1 (дата звернення: 10.12.2021).

4. Молчанов Н. Психология ценообразования: 10 психологических эффектов восприятия цены. URL: https://cutt.ly/xYUfUe7 (дата звернення: 10.12.2021).

5. Скригун Н.П., Розумей С.Б. Тактичні прийоми ціноутворення в контексті маркетингових цінових рішень. Наукові праиі Національного університету харчових технологій. 2011. № 40. С. 122-125.

6. Чичуліна К.В., Кладченко Я.О. Сучасні цінові стратегії на основі психології. Глобальні та національні проблеми економіки. 2018. Вип. 23. С. 352-355.

\section{References:}

1. Bespaliuk Kh.M., Horbal N.I., Denysiuk O.V. (2018) Psykholohichni chynnyky pry formuvanni taktyky tsinoutvorennia [Psychological factors in the formation of pricing tactics]. Marketynh $i$ menedzhment innovatsii, no. 1, pp. 141-151. (in Ukrainian)

2. Komyssarov K. Psykholohyia tseny [Psychology of Pricing]. URL: https://cutt.ly/HYUtSo3 (accessed 10 December 2021).

3. Mayorov I.G., Mayorova N.G. (2020) Psikhologicheskiye metody tsenoobrazovaniya [Psychological methods of pricing]. Innovatsii. Nauka. Obrazovaniye, no. 15, pp. 28-39. URL: https://cutt.ly/MYItIP1 (accessed 10 December 2021).

4. Molchanov N. Psykholohyia tsenoobrazovanyia: 10 psykholohycheskykh effektov vospryiatyia tseny [Psychology of pricing: 10 psychological effects of price perception]. URL: https://cutt.ly/xYUfUe7 (accessed 10 December 2021).

5. Skryhun N.P., Rozumei S.B. (2011) Taktychni pryiomy tsinoutvorennia v konteksti marketynhovykh tsinovykh rishen [Tactical receptions of pricing in context of marketings price decisions]. Naukovi pratsi Natsionalnoho universytetu kharchovykh tekhnolohii, no. 40, pp. 122-125. (in Ukrainian)

6. Chychulina K.V., Kladchenko Y.O. (2018) Suchasni tsinovi stratehii na osnovi psykholohii [Modern price strategies based on psychology]. Hlobalni ta natsionalni problemy ekonomiky, vol.23, pp. 352-355. (in Ukrainian) 